\title{
IMPLEMENTASI KURIKULUM 2013 TERHADAP SIKAP PESERTA DIDIK DALAM PEMBELAJARAN PENDIDIKAN AGAMA ISLAM
}

\author{
Fatimah $^{1}$, Rusli Malli ${ }^{2}$ \\ ${ }^{* 1}$ Pendidikan Agama Islam Fakultas Agama Islam| Unismuh Makassar \\ ${ }^{* 2}$ Pendidikan Agama Islam Fakultas Agama Islam| Unismuh Makassar
}

\begin{abstract}
ABSTRAK
Jenis penelitian yang digunakan adalah deskriptif kualitatif. Populasi dalam penelitian ini adalah semua siswa dan guru PAI sebanyak 104. Adapun teknik yang digunakan adalah teknik puporsife sampling yaitu sampel diambil secara langsung atau sengaja yakni siswa kelas 2,4,5 sebanyak 53 orang . selanjutnya pengumpulan data melalui penelitian kepustakaan dan lapangan yang terdiri dari teknik observasi, wawancara, angket dan catatan dokumentasi. Adapun teknik analisis data yang digunakan adalah dengan cara deskriftif kualitatif. Dari hasil penelitian menunjukkan bahwa implementasi kurikulum 2013 dalam pembelajaran Pendidikan Agama Islam yang berkaitan dengan pemahaman guru dalam membuat perangkat pembelajaran di SDN.16 Tanrutedong Kabupaten Sidrap sudah berjalan dengan baik dilihat dari pemahaman guru sudah mampu membuat perangkat pembelajaran seperti silabus, rencana pelaksanaan pembelajaran(RPP) dan memahami rubrik-rubrik penilaian peserta didik. Adapun sikap peserta didik terhadap pembelajaran Pendidikan Agama Islam terbilang sangat baik dilihat dari perilaku sehari-hari siswa dan dapat dilihat dari hasil kusioner tentang sikap siswa dalam mengikuti pembelajaran Pendidikan Agama Islam. Sedangkan kendala Implementasi Kurikulum 2013 mengalami beberapa kendala
\end{abstract}

Kata Kunci : Implementasi Kurikulum 2013, sikap, pembelajaran

\begin{abstract}
The type of research used is descriptive qualitative. The populations in this study are all students and teachers of PAI as much as 104. The technique used is the technique of sampling is samples taken directly or deliberately 2.4 .5 class of students as many as 53 people. Data collection through literature and field research consisting of observation techniques, interviews, questionnaires and documentation records. The data analysis technique used is descriptive qualitative way. The result of the research shows that the implementation of curriculum 2013 in the learning of Islamic Religious Education related to the understanding of teachers in making learning tools in SDN.16 Tanrutedong Sidrap Regency has been running well from the understanding of teachers have been able to make learning tools such as syllabus, learning implementation plan (RPP ) And understand the scoring rubrics of learners. The attitude of learners to learning Islamic Religious Education is very well seen from the daily behavior of students and can be seen from the results of a questioner about the attitude of students in following the learning of Islamic Education. While obstacles Implementation Curriculum 2013 experienced several obstacles
\end{abstract}

Keywords: Curriculum Implementation of 2013, attitude, learning 


\section{PENDAHULUAN}

Pendidikan merupakan unsur utama dalam pengembangan manusia indonesia seutuhnya. Oleh karena itu, pengelolaan pendidikan harus berorientasi kepada bagaimana menciptakan perubahan yang lebih baik. Membahas tentang pendidikan pastilah tidak lepas dari kurikulum. Karena kurikulum merupakan alat yang sangat penting bagi keberhasilan suatu pendidikan. Kurikulum ibarat jantung pendidikan, jika jantung itu berfungsi dengan baik maka keseluruhan badanpun akan berfungsi dengan baik. Tanpa kurikulum yang tepat, maka suatu tujuan dan sasaran dari pendidikan akan sulit dicapai.

Suatu kurikulum harus terus beradaptasi dengan berbagai perubahan dan perkembangan yang ada. Oleh karena itu, perubahan kurikulum adalah sesuatu yang memang sangat mungkin terjadi. Kurikulum akan secara terus menerus mengalami perubahan agar suatu kurikulum mampu menjawab tantangan zaman yang terus berubah tanpa dapat dicegah, dan untuk mempersiapkan peserta didik yang mampu bersaing dimasa depan dengan segala kemajuan ilmu pengetahuan dan teknologi. (Imas Kurniasih dan Berlin sani,2013:3).

Salah satu upaya yang ditempuh dengan menerapkan Kurikulum 2013 yang disusun dengan dilandasi pemikiran-pemikiran masa depan. Dimana kurikulum 2013 merupakan serentetan rangkaian penyempurnaan terhadap kurikulum yang telah dirintis tahun 2004 yang berbasis kompetensi lalu diteruskan dengan kurikulum 2006.

Kurikulum 2013 adalah sebuah kurikulum yang dikembangkan untuk meningkatkan dan menyeimbangkan kemampuan soft skills dan hard skills berupa sikap, keterampilan, dan pengetahuan. Dalam konteks ini, kurikulum 2013 berusaha untuk lebih menanamkan nilai-nilai yang tercermin pada sikap dapat berbanding lurus dengan keterampilan yang diperoleh peserta didik melalui pengetahuan dibangku sekolah.(Fadlillah,2014:16)

Diantara aspek yang terdapat dalam kurikulum 2013 adalah sikap spiritual dan sikap sosial. Artinya, dengan sikap spiritual, peserta didik akan memiliki moral atau etika yang baik dalam kehidupannya. Selain itu, sikap ini merupakan perwujudan antar seorang hamba dengan Tuhan Yang Maha Esa. Oleh karenanya, apa yang dilakukannya pun harus sesuai dengan apa yang diperintahkan-Nya. Aspek sosial merupakan gambaran bentuk hubungan dengan sesama manusia dan juga lingkungannya. Aspek ini akan mengajarkan kepada peserta didik tentang pentingnya hubungan sosial. Disamping itu, manusia adalah makhluk sosial yang membutuhkan bantuan orang lain. Lebih-lebih nanti setelah peserta didik menyelessaikan studinya, pasti akan kembali kepada masyarakat. Maka dari itu, peserta didik harus memilki bekal yang cukup dalam bersosialisasi dengan 
lingkungan sekitarnya. (Fadlillah, 2014:49).

Tentunya sebagai orang yang beragama Islam segala aspek kehidupan akan diatur dalam al-qur'an dan as-sunnah sebagai pedoman hidup. Berkaitan dengan hal itu peserta didik akan mendapatkan pembelajaran itu dalam Pendidikan Agama Islam sebagai salah satu mata pembelajaran peserta didik di sekolah. Namun, adanya sikap peserta didik yang biasanya kurang meminati bahkan kurangnya motivasi dalam mengikuti pembelajaran Pendidikan Agama Islam sehingga menghasilkan pembelajaran yang kurang optimal dalam diri mereka. Adapun pokok bahasan mengenai

1. Bagaimana Implementasi Kurikulum 2013 dalam Pembelajaran Pendidikan Agama Islam di SDN 16 Tanrutedong Kabupaten Sidrap?

2. Bagaimana sikap peserta didik terhadap mata pelajaran Pendidikan Agama Islam di SDN. 16 Tanrutedong Kabupaten Sidrap ?

\section{METODE PENELITIAN}

Penelitian ini bersifat deskriftif kualitatif yaitu untuk mengambarkan implementasi kurikulum 2013 terhadap sikap peserta didik dalam pembelajaran Pendidikan Agama Islam di SDN.16 Tanrutedong Kabupaten Sidrap Variabel dalam penelitian ini adalah "Implementasi Kurikulum 2013 Terhadap Sikap Peserta Didik Dalam
Pembelajaran Agama Islam di SDN.16 Tanrutedong Kabupaten Sidrap".

Pada penelitian ini menggunakan 2 variabel yakni variabel bebas dan variabel terikat,

a. Variabel bebas dari penelitian ini adalah implementasi kurikulum 2013

b. Variabel terikat dari penelitian ini adalah sikap peserta didik dalam pembelajaran Pendidikan Agama Islam di SDN.16 Tanrutedong Kabupaten Sidrap.

Tabel 1. Populasi

\begin{tabular}{|l|l|c|c|c|}
\hline \multirow{2}{*}{ No } & \multirow{2}{*}{ Kelas } & \multicolumn{2}{|c|}{$\begin{array}{c}\text { Jenis } \\
\text { kelamin }\end{array}$} & \multirow{2}{*}{ Jumlah } \\
\cline { 3 - 4 } & & LK & PR & \\
\hline 1. & Kelas I & 8 & 6 & 14 \\
\hline 2. & Kelas II & 12 & 4 & 17 \\
\hline 3. & $\begin{array}{l}\text { Kelas } \\
\text { III }\end{array}$ & 5 & 8 & 13 \\
\hline 4. & $\begin{array}{l}\text { Kelas } \\
\text { IV }\end{array}$ & 6 & 7 & 12 \\
\hline 5. & Kelas V & 10 & 13 & 23 \\
\hline 6. & $\begin{array}{l}\text { Kelas } \\
\text { VI }\end{array}$ & 14 & 10 & 24 \\
\hline 7. & $\begin{array}{l}\text { Guru } \\
\text { PAI }\end{array}$ & 1 & - & 1 \\
\hline \multicolumn{2}{|l|}{ Jumlah total } & 56 & 48 & 104 \\
\hline
\end{tabular}

Table II. Sampel

\begin{tabular}{|l|l|l|l|l|}
\hline \multirow{2}{*}{ No } & \multirow{2}{*}{ Kelas } & \multicolumn{2}{|c|}{$\begin{array}{c}\text { Jenis } \\
\text { kelamin }\end{array}$} & \multirow{2}{*}{ Jumlah } \\
\cline { 3 - 4 } & & LK & PR & \\
\hline
\end{tabular}




\begin{tabular}{|l|l|c|c|c|}
\hline 1. & Kelas II & 12 & 4 & 16 \\
\hline 2. & $\begin{array}{l}\text { Kelas } \\
\text { IV }\end{array}$ & 6 & 7 & 13 \\
\hline 3. & Kelas V & 10 & 13 & 23 \\
\hline 4. & $\begin{array}{l}\text { Guru } \\
\text { PAI }\end{array}$ & 1 & - & 1 \\
\hline & $\begin{array}{l}\text { Jumlah } \\
\text { total }\end{array}$ & 29 & 24 & 53 \\
\hline
\end{tabular}

sistem Kurikulum, sebagai standar acuan dalam proses pembelajaran di sekolah.

SDN.16 Tanrutedong merupakan sekolah yang mempunyai salah satu misi yaitu Memenuhi standar Kurikulum Tingkat Satuan Pendidikan (KTSP) 2013 yang sesuai dengan kebutuhan siswa mengem-bangkan kompetensi yang diperlukan-nya.

Instrumen penelitian data pada penelitian ini dilakukan melalui observasi, wawancara, angket dan dokumentasi yaitu Pedoman observasi, Pedoman wawancara, Pedoman angket dan Pedoman dokumentasi

\section{HASIL PENELITIAN DAN PEMBAHASAN}

\section{A. Implementasi Kurikulum 2013 dalam Pembelajaran Pendidi- kan Agama Islam}

Dinamika perkembangan pendidikan Indonesia salah satu indikatornya dapat dilihat dai terjadinya perubahan kurikulum. Hal ini berangkat dari kesadaran bahwa Kurikulum merupakan salah satu media untuk mencapai tujuan Pendidikan yang diharapkan dapat terlaksana dengan baik. Dalam upaya memperbaiki sistem Pendidikan Nasional, maka Pemerintah telah melakukan berbagai macam untuk mencapai tujuan Pendidikan Nasional, yakni untuk mencerdaskan anak-anak bangsa. Salah satu upaya yang ditempuh adalah melalui perbaikan Sering adanya perkembangan zaman lembaga pedidikan telah memperbaharui KTSP menjadi kurikulum 2013. Salah satu upaya sekolah dalam mewujudkan/ menghasilkan peserta didik yang berkualitas maka pihak sekolah ikut merealisasikan Kurikulum 2013. Di mana Kurikulum 2013 berusaha untuk lebih menanamkan nilai-nilai yang tercermin pada sikap dapat berbanding lurus dengan keterampilan yang diperoleh peserta didik melalui pengetahuan dibangku sekolah.

\section{B. Sikap Peserta Didik Dalam Pembelajaran Pedidikan Islam di SDN.16 Tanrutedong Kabupaten Sidrap}

Belajar adalah proses melihat, mengamati, dan memahami sesuatu yang dipelajari dan menghasilkan perubahan pada pengetahuan serta menghasilkan perubahan pada sikap. Berkaitan dengan Kurikulum 2013, maka sikap yang dimaksud adalah pembentukan karakter pada setiap peserta didik. Adapun pembentukan karakter yang dinilai oleh seorang guru 
di SDN.16 Tanrutedong Kabupaten Sidrap secara berkesinambungan dengan menggunakan indera diantaranya sebagai berikut:

1. Sikap spiritual peserta didik

2. Kedisiplinan siswa

3. Kesopanan siswa

4. Kejujuran siswa

5. Tanggung jawab siswa

6. Percaya diri siswa

Adapun sikap siswa terhadap mata pelajaran Pendidikan Agama Islam yang dimaksud yaitu adanya motivasi dan kebutuhan, minat, konsep diri, perhatian serta bakat pada siswa dalam mengikuti pembelajaran pendidikan agama islam di kelas.

Berdasarkan uraian di atas, maka untuk mengetahui sikap peserta didik dalam pembelajaran Pendidikan Agama Islam di SDN.16 Tanrutedong Kabupaten Sidrap peneliti menggunakan kusioner kepada siswa

Hasil tabulasi dari kusioner tersebut dapat peneliti paparkan persentase setiap item sebagai berikut:

Table III

Minat siswa terhadap pembelajaran Pendidikan Agama Islam

\begin{tabular}{|c|l|c|c|}
\hline $\begin{array}{c}\text { No } \\
\text {. }\end{array}$ & Jawaban & $\begin{array}{c}\text { Frekue } \\
\text { nsi }\end{array}$ & $\begin{array}{c}\text { Persent } \\
\text { ase }\end{array}$ \\
\hline 1. & $\begin{array}{l}\text { Sangat } \\
\text { senang }\end{array}$ & 50 & $94 \%$ \\
\hline 2. & $\begin{array}{l}\text { Cukup } \\
\text { senang }\end{array}$ & 3 & $6 \%$ \\
\hline 3. & $\begin{array}{l}\text { Tidak } \\
\text { senang }\end{array}$ & 0 & $0 \%$ \\
\hline \multicolumn{2}{|c|}{ Jumlah } & 53 & $100 \%$ \\
\hline
\end{tabular}

Dari tabel di atas dapat diketahui bahwa ada sekitar 50 orang ssiwa atau 94\% peserta didik sangat senang belajar pendidikan agama islam di kelas, sedangkan yang menjawab cukup senang sekitar 3 orang siswa atau $6 \%$ dan tidak ada siswa yang tidak senang atau $0 \%$ tehadap pembelajaran Pedidikan Agama Islam.

\section{Tabel IV}

Pentingya pembelajaran

Pendidikan Agama Islam bagi siswa

\begin{tabular}{|c|c|c|c|}
\hline $\begin{array}{c}\text { No } \\
\text {. }\end{array}$ & $\begin{array}{c}\text { Jawaba } \\
\text { n }\end{array}$ & $\begin{array}{c}\text { Frekuen } \\
\text { si }\end{array}$ & $\begin{array}{c}\text { Persenta } \\
\text { se } \\
\end{array}$ \\
\hline 1. & $\begin{array}{l}\text { Sangat } \\
\text { penting }\end{array}$ & 45 & $85 \%$ \\
\hline 2. & Penting & 8 & $15 \%$ \\
\hline 3. & $\begin{array}{l}\text { Kurang } \\
\text { penting }\end{array}$ & 0 & $0 \%$ \\
\hline \multicolumn{2}{|c|}{ Jumlah } & 53 & $100 \%$ \\
\hline
\end{tabular}

Sumber data : Hasil tabulasi kusioner item nomor 2

Dari tabel di atas dapat diketahui bahwa ada sekitar 45 orang siswa atau $85 \%$ peserta didik menganggap pembelajaran Pendidikan Agama Islam sangat penting bagi siswa, sedangkan yang menjawab cukup penting sekitar 8 orang siswa atau $15 \%$ dan tidak ada atau $0 \%$ orang siswa yang menganggap Pendidikan Agama Islam tidak penting.

\section{Tabel V}

Motivasi peserta didik terhadap pembelajaran Pendidikan Agama Islam 


\begin{tabular}{|c|l|c|c|}
\hline $\begin{array}{c}\text { No } \\
\text {. }\end{array}$ & $\begin{array}{c}\text { Jawaba } \\
\text { n }\end{array}$ & $\begin{array}{c}\text { Frekue } \\
\text { nsi }\end{array}$ & $\begin{array}{c}\text { Persenta } \\
\text { se }\end{array}$ \\
\hline 1. & $\begin{array}{l}\text { Sangat } \\
\text { rajin }\end{array}$ & 47 & $88 \%$ \\
\hline 2. & $\begin{array}{l}\text { Kadang- } \\
\text { kadang } \\
\text { rajin }\end{array}$ & 3 & $6 \%$ \\
\hline 3. & $\begin{array}{l}\text { Kurang } \\
\text { rajin }\end{array}$ & 3 & $6 \%$ \\
\hline \multicolumn{2}{|c|}{ Jumlah } & 53 & $100 \%$ \\
\hline
\end{tabular}

Dari tabel di atas dapat diketahui bahwa ada sekitar 47 orang ssiwa atau $88 \%$ yang menjawab sangat rajin yang artinya peserta didik memilki motivasi terhadap pembelajaran Pendidikan Agama Islam di kelas, sedangkan yang menjawab kadang termotivasi belajar Pendidikan Agama Islam sekitar 3 orang siswa atau $6 \%$ dan ada 3 orang siswa atau $6 \%$ orang siswa yang tidak memilki motivasi dalam mengikuti pembelajaran Pendidikan Agama Islam.

\section{Tabel VI}

Perhatian peserta didik terhadap pembelajaran Pendidikan Agama

Islam

\begin{tabular}{|c|l|c|c|}
\hline $\begin{array}{c}\text { No } \\
\cdot\end{array}$ & Jawaban & $\begin{array}{c}\text { Frekue } \\
\text { nsi }\end{array}$ & $\begin{array}{c}\text { Persent } \\
\text { ase }\end{array}$ \\
\hline 1. & $\begin{array}{l}\text { Sangat } \\
\text { serius }\end{array}$ & 47 & $89 \%$ \\
\hline 2. & Serius & 6 & $11 \%$ \\
\hline 3. & $\begin{array}{l}\text { Kurang } \\
\text { serius }\end{array}$ & 0 & $0 \%$ \\
\hline \multicolumn{2}{|c|}{ Jumlah } & 53 & $100 \%$ \\
\hline
\end{tabular}

Dari tabel di atas dapat diketahui bahwa ada sekitar 47 orang siwa atau $89 \%$ peserta didik yang menjawab sangat serius yang artinya mereka memiliki perhatian terhadap pembelajaran Pendidikan Agama Islam di kelas, sedangkan yang menjawab serius dalam belajar Pendidikan Agama Islam sekitar 6 orang siswa atau $11 \%$ dan tidak ada orang siswa atau $0 \%$ orang siswa yang kurang dalam mengikuti pembelajaran Pendidikan Agama Islam.

\section{Tabel VI}

Prestasi peserta didik terhadap pembelajaran Pendidikan Agama Islam

\begin{tabular}{|c|l|c|c|}
\hline No & Jawaban & $\begin{array}{c}\text { Frekue } \\
\text { nsi }\end{array}$ & $\begin{array}{c}\text { Persent } \\
\text { ase }\end{array}$ \\
\hline 1. & $\begin{array}{l}\text { Sangat } \\
\text { berpresta } \\
\text { si }\end{array}$ & 39 & $75 \%$ \\
\hline 2. & $\begin{array}{l}\text { Berpresta } \\
\text { si }\end{array}$ & 12 & $22 \%$ \\
\hline 3. & $\begin{array}{l}\text { Kurang } \\
\text { berpresta } \\
\text { si }\end{array}$ & 2 & $3 \%$ \\
\hline \multicolumn{2}{|c|}{ Jumlah } & 53 & $100 \%$ \\
\hline
\end{tabular}

Sumber data : Hasil tabulasi kusioner item nomor 7

Dari tabel atas dapat diketahui bahwa ada sekitar 49 orang siswa atau 92\% peserta didik memiliki prestasi yang tinggi terhadap pembelajaran Pendidikan Agama Islam di kelas, sedangkan yang menjawab berprestasi dalam belajar pendidikan agama islam sekitar 3 orang siswa atau $6 \%$ dan ada 
1 orang siswa atau $2 \%$ orang siswa yang kurang memiliki prestasi dalam pembelajaran Pendidikan Agama Islam.

\section{Kendala Implementasi Kurikulum 2013 dalam Pembelajaran Pendidikan Agama Islam di SDN.16 Tanrutedong Kabupaten Sidrap}

Ada beberapa kendala dalam penerapan Kurikulum 2013 yaitu sebagai berikut:

1. Teknologi sekolah kurang memadai. Dalam melaksanakan proses pembelajaran diperlukan sarana misalnya teknologi berupa LCD. Misalnya, seorang guru melakukan proses belajar mengajar dengan memperlihatkan tampilantampilan gambar yang berkaitan dengan pembelajaran yang dilaksanakan. Namun, karena sarana dan prasarana di sekolah minim maka seorang guru menganggap hal itu merupakan suatu kendala dalam proses belajar mengajar. Terlebih lagi bagi sekolah-sekolah yang berada dipedalaman bagi mereka sangat rumit untuk melakukan pembelajaran yang sesuai dengan kurikulum 2013.

2. Materi yang terdapat dibuku sangat sedikit sehingga dalam melaksanakan pembelajaran guru harus lebih banyak berbicara dibanding siswa. Oleh karena itu, pembelajaran berjalan tidak sesuai tuntunan Kurikulum 2013 dimana siswa diharapkan lebih aktif.

3. Daftar penilaian yang rumit. Ada beberapa aspek penilaian yang harus diisi oleh seorang guru sehingga dalam satu siswa membutuhkan beberapa lembar penilaian. Selain itu penilaian sikap pada peserta didik tidak hanya dilakukan di kelas namun dilakukan juga diluar kelas.

Selain yang kendala yang disebutkan terdapat juga kendala lain yang dikemukakan oleh Asribing selaku Guru Pendidikan Agama Islam di SDN.16 Tanrutedong Kabupaten Sidrap bahwa:

"Kendala lain dalam penerapan Kurikulum 2013 yaitu terlambatnya buku-buku pembelajaran. Akibatnya pada awal penerapan kurikulum 2013 materi hanya dicopikan kemudian dibagikan kepada siswa sebagai materi belajar. Disisi lain setelah penerapan kurikulum itu para siswa mengeluh karena siswa hanya mempunyai kesempatan istirahat satu kali padahal sebelumnya mereka istirahat dua kali sebelum pulang sekolah" (wawancara 21 juli 2015).

Adapun solusi untuk mengatasi kendala Implementasi Kurikulum 2013 di atas sebagai berikut:
1. Pihak sekolah
senantiasa memperhatikan kelengkapan sarana-sarana yang dibutuhkan dalam proses pembelajaran. Selain 
itu, guru juga menyediakan media yang akan dibutuhkan dalam proses pembelajaran.

2. Guru menyiapkan referensi buku yang dapat menunjang pembelajaran yang diajarkan. Selain itu, seorang Guru juga kreatif mengelolah pembelajaran sehingga tujuan pembelajaran dapat tercapai dengan maksimal.

3. Guru dituntut untuk memahami daftar-daftar penilaian tersebut sebagai wujud guru yang profesional dalam bidang Pendidikan.

\section{KESIMPULAN}

Berdasarkan pada uraian sebelumnya maka pada bab ini penulis mengemukakan beberapa kesimpulan antara lain:

1. Implementasi Kurikulum 2013 dalam Pembelajaran Pendidikan Agama Islam di SDN.16 Tanrutedong Kabupaten Sidrap adalah sudah berjalan dengan baik karena guru sudah mampu membuat perangkat pembelajaran dan memahami daftar-daftar penilaian peserta didik

2. Sikap peserta didik terhadap pembelajaran Pendidikan Agama Islam di SDN.16 Tanrutedong Kabupaten Sidrap sudah baik dapat dilihat sikap sehari-harinya maupun sikapnya terhadap pembelajaran Pendidikan Agama Islam

3. Kendala implementasi Kurikulum 2013 dalam pembelajaran
Pendidikan Agama Islam yaitu terdapat beberapa kendala misalnya teknologi di sekolah kurang memadai, materi buku yang sangat sedikit, daftar penilaian yang rumit dan lain-lain. Oleh karena seorang guru memang dituntut menjadi guru yang profesional.

\section{DAFTAR PUSTAKA}

Albone, Abd.azis.Pendidikan Agama Islam Dalam Perspektif Multikulturalisme. Cet.1: Balai Penelitian dan Pengembangan Agama Jakarta

Arifin.1994. Ilmu Pendidikan Islam suatu tinjauan teoritis dan praktis berdasarkan pendekatan interdisipliner.Bumi

Aksara:Jakarta

Arikunto,Suharsimi.2002.Prosedur

Penelitian Suatu Pendekatan

Praktek.Cet.12.Rineka Cipta :Jakarta

Komalasari,Kokom.

2011.

Pembelajaran Kontekstual

Konsep dan Aplikasi. Refika ADITAMA: Bandung

Muhaimin. 2007. Pengembangan Kurikulum Pendidikan Agama Islam di

Sekolah, Madrasah dan Perguruan Tinggi. Edisi 1-2. PT.Raja Grafindo Persada. Jakarta

Prasetyo,Ahmadi. 1997. Strategi Belajar Mengajar untuk fakultas tarbiyah komponen MKDK. CV.Pustaka Setia: Bandung 
Prihatin.2011. Manajemen peserta

Didik. Cet.1. Alfabeta:Bandung

Sani,Kurniasih. 2014. Implementasi

Kurikulum 2013 Konsep dan

Penerapan. Cet.4. Kata

Pena:Surabaya

Sani,Kurniasih. 2013. Sukses

Mengimplementasikan

Kurikulum 2013 Memahami

Berbagai aspek dalam kurikulum

2013.cet.2:kata Pena

Sardiman. 2012. Interaksi dan

Motivasi Belajar Mengajar.

Rajawali Pers: Jakarta

Slameto. 2010. Belajar dan Faktor-

Faktor yang Mempengaruhinya.

Rineka Cipta: Jakarta

Sugiyono. 2013. Metode Penelitian

Pendidikan Pendekatan

Kuantitatif,Kualitatif,dan

$R \& D$.Bandung:Alfabeta

Sugiyono. 1998. Metode Penelitian administrasi. Cet.5.

ALFABETA: Bandung

Suprihatiningrum. 2013. Strategi

Pembelajaran Teori dan

Aplikasi. Ar-Ruzz Media:

Jogjakarta

Suryosubroto. 2002. Proses Belajar

Mengajar di Sekolah. Cet.1.

PT.RINEKA CIPTA: Jakarta

Tohirin. 2011. Psikologi Pendidikan

Agama Islam.Cet.4. Jakarta:

Rajawali Pers

Undang-Undang Republik Indonesia

Nomor:14 Tahun 2005 Tentang

Guru dan Dosen,2007, Indonesia

Legal Center Publishing. 